\title{
Uyghur Legitimation and the Role of Buddhism
}

\author{
Yukiyo Kasai
}

In the middle of the 8th century, Uyghurs, a Turkic speaking nomadic tribe, established their Empire, the East Uyghur Kaganate (ca. 744-840), in Mongolia. After the demise of this Kaganate, most of them moved into the eastern part of the Tianshan (天山) area, where they founded a new kingdom, the West Uyghur Kingdom (second half 9th c.-13th c.). This kingdom continued to exist even after the rise of Činggiz Khan (1162?-1227), to whom the Uyghur king at that time voluntarily submitted. Throughout this extended period, the Uyghurs experienced many cultural, religious, and political changes that had an impact on representations of their rulers' power. This chapter discusses how the Uyghur rulers officially tried to legitimate their power based on their different beliefs and political relationships.

The Uyghur rulers' official titles are essential to their legitimation strategies because they reflect the rulers' intentions concerning how they want to formally represent themselves. In this chapter, I investigate which official titles were used by the Uyghur rulers during the above-mentioned period. However, with the establishment of the Mongol Empire (1206), the position of the Uyghur rulers shifted into a different stage, so this period will be dealt with below.

\section{Period of the East Uyghur Kaganate}

\subsubsection{Nomadic Tradition}

After its foundation, the East Uyghur Kaganate extended its influence beyond Mongolia. The Uyghurs, with their considerable military power, were one of

1 I would like first to express my sincere thanks to Dr. Miki Morita (Iwakuni), Prof. Emiko Tsukamoto (Kyoto), Dr. Jens Wilkens (Göttingen), and Prof. Yutaka Yoshida (Kyoto), who kindly gave me their specialist support. Of course, I alone am responsible for my mistakes. 
the most important neighbouring states to the Tang Dynasty (618-907, 唐), which was the greatest power in Eastern and Central Asia at that time. At times, it even posed a threat to the Tang. Thus, the activities of the Uyghurs were carefully monitored by the Chinese. As a result, many reports on the Uyghurs and their Kaganate entered into the official chronicle of the Tang Dynasty. There, the Uyghur rulers' official titles were mostly mentioned in reports concerning the enthronement of new rulers. In addition, three official stone monuments were established by the Uyghurs themselves, i.e. Šine-Usu, Sevrey, and Karabalgasun. ${ }^{2}$ While the first of these was devoted to the second ruler (r. 747-759), the second was established during the period of the eighth ruler (r. 8o8-821). Several scholars have suggested different theories regarding the setting up of the Sevrey Inscription. According to Yukata Yoshida, it was established by the third ruler (r. 759-779), when he came to China to help fight on the imperial side in the rebellion of An Lushan (703-757, 安祿山). ${ }^{3}$ The Karabalgasun Inscription in particular is remarkable because it is written in three

2 For the most recent research on these inscriptions, see e.g. Moriyasu Takao 森安孝夫 et al., “Shineusu hibun yakuchū シネウス碑文訳注 [Šine-Usu Inscription from the Uyghur Period in Mongolia: Revised Text, Translation and Commentaries]," Nairiku ajia gengo no kenkyū 内 陸アジア言語の研究 [Studies on the Inner Asian Languages] 24 (2009): 1-92; Moriyasu Takao 森安孝夫 et al., "Seburei hibun セブレイ碑文 [Sevrey Inscription]," in Mongorukoku genzon iseki, hibun chōsa kenkyū hōkoku モンゴル国現存遺蹟・碑文調查研究報告 [Provisional Report of Researches on Historical Sites and Inscriptions in Mongolia from 1996 to 1998], ed. Takao Moriyasu 森安孝夫 and Ayudai Ochir (Toyonaka: The Society of Central Eurasian Studies, 1999), 225-227; Moriyasu Takao 森安孝夫 et al., "Kara = Barugasun hibun カラ＝バルガスン碑文 [Karabalgasun Inscription]," in Mongorukoku genzon iseki, hibun chōsa kenkyū hōkoku モンゴル国現存遺蹟・碑文調查研究報告 [Provisional Report of Researches on Historical Sites and Inscriptions in Mongolia from 1996 to 1998], ed. Takao Moriyasu 森安孝夫 and Ayudai Ochir (Toyonaka: The Society of Central Eurasian Studies, 1999), 209-224; Yoshida Yutaka 吉田豊, “Sogudojin to kodai no Churukuzoku tono kankei ni kansuru mittsu no oboegaki ソグド人と古代のチュルク族との関係に関する三つの覚え 書き [Three Philological Notes on the Sogdo-Turkish Relationship]," Kyōto daigaku bungakubu kenkyū kiyo 京都大學文學部研究紀要 [Memoirs of the Faculty of Letters Kyoto University] 50 (2011): 7-22; Yoshida Yutaka 吉田豊, “Sogudojin to torukojin no kankei nit suite no sogudogo shiryō 2 -ken ソグド人とトルコ人の関係についてのソグド語資料 2 件 [Two Sogdian materials concerning the Turco-Sogdian relationship]," Seinan Ajia kenkyū 西 南アジア研究 [Middle Eastern Studies] 67 (2007): 52-54; Yutaka Yoshida, "Historical Backgrond of the Sevrey Inscription in Mongolia," in Great Journeys across the Pamir Mountains. Festschrift in Honour of Zhang Guangda on his Eighty-fifth Birthday, ed. Huaiyu Chen and Xinjiang Rong (Leiden, Boston: Brill, 2018), 140-145. Also, the edited Chinese part of the Karabalgasun Inscription is presented as figure 1 in Moriyasu Takao 森安孝夫 and Sakajiri Akihiro 坂尻彰宏, Siruku rōdo to sekaishi シルクロードと世界史 [World History Reconsidered through the Silk Road] (Toyonaka: Osaka University The 21st Century COE Program Interface Humanities Research Activities 2002, 2003).

3 Yoshida, "Two Sogdian Materials," 52-54; Yoshida, "Historical Background," 143-145. 
different languages and scripts (Old Turkish in the Runic script, Chinese, and Sogdian). It features the genealogy of the Uyghur rulers up to the time of the inscription in question. This inscription is now presererved only in fragments, with the Chinese part in a better state of preservation than the other two languages. However, the original Turkish title of the rulers can be reconstructed from the Chinese ones that show the phonetic transcription. Therefore, almost all the official titles of the rulers in the East Uyghur Kaganate, except for the last one, are known (see Table 3.1). ${ }^{4}$

Among the many elements used in the Uyghur rulers' titles, one in particular, played a significant role, Heaven (OT täyri) or heavenly Charisma (OT kut). Heaven was recognised as the source of the nomadic rulers' power as early as the period of the Tujue (fl. 552-742, 突厥), who also belonged to the Turkish speaking nomads and ruled Mongolia as the Uyghur's predecessors. ${ }^{5}$ In the socalled Tonyukuk Inscription, which was established by the famous Tujue chancellor, Tonyukuk (second half of the $7_{\text {th }}$ c.-first half of the 8th c.), the relationship between Heaven, the Turkish rulers, and their people is clearly described:

However, Täyri said: 'I gave (you) a ruler. You, however, left your ruler (and anew) submitted'. Because (you) submitted, Täyri said 'Die!' (And) the Türk clans died, collapsed, and were killed off. ${ }^{6}$

The Uyghurs inherited the same idea about Heaven, evidenced in the short sentence in the Šine-Usu Inscription:

4 The Uyghur rulers' titles are well researched. They appear in the table based on the following works, see e.g. Moriyasu Takao 森安孝夫, “Uiguru = Manikyō shi no kenkyū ウイグル=マニ 教史の研究 [A Study on the History of Uyghur Manichaeism-Research on Some Manichaean Materials and their Historical Background]," Ōsaka daigaku bungakubu kiyō 大阪大学文学部紀要 [Memoirs of the Faculty of Letters Osaka University] 31/32 (1991): 182-183; Takao Moriyasu, Die Geschichte des uigurischen Manichäismus an der Seidenstraße. Forschungen zu manichäischen Quellen und ihrem geschichtlichen Hintergrund (Wiesbaden: Harrassowitz, 2004), 221-222. Volker Rybatzki analysed each title of the rulers in detail, see Volker Rybatzki, "Titles of Türk and Uigur Rulers in the Old Turkic Inscriptions," Central Asiatic Journal 44.2 (2000): 224-225, 251. Some of those titles are reconstructed based on the Chinese phonetic transcriptions.

5 This topic has been discussed by several scholars, see e.g. Masao Mori, "The T'u-Chüeh Concept of Sovereign," Acta Asiatica 41 (1981): 47-75; Peter B. Golden, "Imperial Ideology and the Sources of Political Unity Amongst the Pre-Činggisid Nomads of Western Eurasia," in Nomads and Their Neighbours in the Russian Steppe, Turks, Khazars and Qipchaqs, ed. Peter B. Golden (Burlington: Routledge, 2003), 42-5o.

6 The sentence was originally translated by Volker Rybatzki into German, see Volker Rybatzki, Die Toñuquq-Inschrift (Szeged: University of Szeged, 1997), 79, lines 2-3. 
TABLE 3.1 The titles of the rulers in the East Uyghur Kaganate

Number Title (in Old Uyghur and Chinese) ${ }^{\mathrm{a}} \quad$ Ruling period

$1 \quad$ köl bilgä kagan

744-747

閭毗伽可汗

täyridä bolmıš el itmiš bilgä kagan

$747-759$

[登里]囉沒蜜施頡毉德蜜施毗伽可汗

täyridä kut bulmıš el tutmıš alp külüg bilgä kagan

759-779

登里囉汨沒蜜施頡咄登蜜施合俱録毗伽可汗

alp kutlug bilgä kagan

$779-789$

合骨咄祿毗伽可汗

täyridä bolmıš külüg bilgä kagan

789-79o

登里囉沒蜜施俱録毗伽可汗

$6 \quad$ kutlug bilgä kagan

790-795

汨咄祿毗伽可汗

täyridä ülüg bulmıš alp kutlug ulug bilgä kagan

$795^{-8 \circ 8}$

登里囉羽録沒蜜施合泪咄祿胡祿毗伽可汗

ay täyridä kut bulmıš alp bilgä kagan

$808-821$

愛登里囉泪沒蜜施合毗伽可汗

kün tärridä ülüg bulmıš alp küčlüg bilgä kagan

$821-824$

君登里邏羽録沒蜜施合句主録毗伽可汗

ay täyridä kut bulmıš alp bilgä kagan

$824-832$

愛登里囉泪沒蜜施合毗伽可汗

a In the following discussion, some but not all of the elements in the titles are particularly relevant. The English translations are given for the elements discussed below.

The heaven-god and the earth-god deigned to tell (me) that the (Turkic) people were my (i.e. the Qayan's) slaves. ${ }^{7}$

This sentence mentions the earth-god in addition to the heaven-god. However, Heaven undoubtably played an important role. The titles that indicate

7 Moriyasu et al., "Šine-Usu Inscription,” 25, lines E1-2. 
Heaven as the source of the heavenly Charisma of the rulers reflect a nomadic tradition. ${ }^{8}$

\subsubsection{Influence of Manichaeism}

In the East Uyghur Kaganate, a radical change took place with regard to Uyghur beliefs. The third ruler decided to accept Manichaeism as the primary religion and promised to give his favours to its church and followers. ${ }^{9}$ There are two reasons for the conversion of this ruler to Manichaeism: an outward one concerning politics and a rather inward one concerning economics. The ruler "needed one world religion to represent his empire, which has to be different from those of the rival empires, i.e. Tibetan Buddhism, Chinese Taoism, Judaism of Khazar, and so on."10 The other factor in the ruler's adoption of Manichaeism is the crucial connection with Sogdian merchants, who were mostly Manichaean and therefore promised economic advantages. After an inter-religious conflict, from the seventh ruler's period (r. 795-808) onward, the Manichaeans eventually emerged as the winners and from then on received continuous support from the Uyghur rulers.

This essential religious shift affected the legitimation strategies of the Uyghur rulers, which is reflected in their titles. Since the time of the eighth ruler, who is famous for establishing the Karabalgasun Inscription, all rulers have either Moon (OT ay) or Sun (OT kün) as the first element of their titles, which was not previously evident. These celestial objects had a significant

8 See also Hans-Joachim Klimkeit, "Qut: Ein Grundbegriff in der zentralasiatischen Religionsbegegnung," in Humanitas Religiosa. Festschrift für Harald Biezais zu seinem 7o. Geburtstag. Dargebracht von Freunden und Kollegen, ed. L. Neulande (Stockholm: Almquist and Wiksell, 1979), 253-256.

9 About the conversion of the third Uyghur ruler, see e.g. TT II, 411-422; Larry V. Clark, "The Conversion of Bügü Khan to Manichaeism," in Studia Manichaica IV. International Kongress zum Manichäismus, Berlin, 14.-18. Juli 1997, ed. Ronald E. Emmerick et al. (Berlin: De Gruyter, 200o), 83-123; Xavier Tremblay, Pour une histoire de la Sérinde. Le manichéisme parmi les peuples et religions d'Asie Centrale d'après les sources primaires (Wien: Verlag der österreichischen Akademie der Wissenschaften, 2001), 108-110; Takao Moriyasu, "New Developments in the History of East Uighur Manichaeism," Open Theology 1 (2015): 319-322.

10 Yoshida Yutaka 吉田豊, “Sogudojin to Sogudo no rekishiソグド人とソグドの歴史 [Sogdians and the Sogdian History]," in Sogudojin no bijutsu to gengo ソグド人の美術と言語 [Sogdian Arts and Languages], ed. Sofukawa Hiroshi 曽布川寛 and Yoshida Yutaka 吉田豊 (Kyoto: Rinsen shoten, 2011), 46; Yutaka Yoshida, "The Eastern Spread of Manichaeism, in Handbook of Manichaeism, ed. Jason BeDuhn (forthcoming), 6. Several scholars present this point of view, and Yoshida mentions individual researchers. The careful choice of religion in political connections with neighbouring states is also pointed out in the case of the Khazar's conversion into Judaism, see Peter B. Golden, "Kharazia and Judaism," Archivum Eurasiae Medii Aevi 3 (1983): 130, 137 . 
function in Manichaen teachings. Thus these elements, especially the Moon element, were added to the ruler's titles because of the Uyghurs' conversion to Manichaeism. ${ }^{11}$ From this we can conclude that since the period of the eighth ruler at the latest, the Uyghur rulers began to use Manichaeian teachings to legitimatise their rule. ${ }^{12}$ Another important reason why they made a Manichaean element visible in their titles is probably that from the seventh ruler onward, the rulers belonged to a different clan than that of former rulers.

\section{2}

\section{Period of the West Uyghur Kingdom}

2.2.1 The Title of the Rulers in the Period of the West Uyghur Kingdom While the official title of the Uyghur rulers is well preserved in the period of the East Uyghur Kaganate, this is not the case for the West Uyghur Kingom, which established itself in the Turfan Basin. After the collapse of East Uyghur Kaganate, the dynasties in China did not pay the Uyghurs in the Turfan Basin much attention anymore. This was because of their long, geographical distance to the West Uyghur Kingdom on the one hand, and because of their overall political instability on the other hand. Thus, while Chinese sources provide the titles of the East Uyghur Kaganate rulers, they do not document the West Uyghur rulers to the same extent. The titles shown in table $3.2^{13}$ are collected

See e.g. Alessio Bombaci, “Qutlug Bolsun!,” Ural-Altaische Jahrbücher 38 (1966): 14; HansJoachim Klimkeit, "Das manichäische Königtum in Zentralasien, "in Documenta Barbarorum. Festschrift für Walther Heissig zum 70. Geburstag, ed. Klaus Sagaster and Michael Weiers (Wiesbaden: Harrassowitz Verlag, 1983), 231-233; Hans-Joachim Klimkeit, "The Sun and Moon as Gods in Central Asia," South Asian Religious Art Studies Bulletin 2 (1983): 11-13; Rybatzki, "Titles of Türk and Uigur Rulers," 245.

The element täyri 'heaven' is still present in the title, so that the traditional idea, that Heaven was the source of the ruling power, possibly played a further role in the legitimation of the Uyghur rulers.

The list of those titles was made on the basis of Takao Moriyasu's, Peter Zieme's, Volker Rybatzki's and Rong Xinjiang's research, see Moriyasu, "Uiguru = Manikyō shi," 183-185; Moriyasu, Die Geschichte des uigurischen Manichäismus, 222-225; Peter Zieme, "Manichäische Kolophone und Könige," in Studia Manichaica. Second International Conference on Manichaeism, St. Augustin/Bonn, August 6-10, 1989, ed. Gernot Wiessner and HansJoachim Klimkeit (Wiesbaden, Harrasowitz: 1992), 323-327; Rybatzki, "Titles of Türk and Uigur Rulers," 252; Hiroshi Umemura, "A Qočo Uyghur King Painted in the Buddhist Temple of Beshbalïq," in Turfan, Khotan und Dunhuang, Vorträge der Tagung „Annemarie von Gabain und die Turfanforschung", veranstaltet von der Berlin-Brandenburgischen Akademie der Wissenschaften in Berlin (9.-12.12. 1994), ed. Ronald E. Emmerick et al. (Berlin: Akademie Verlag, 1996), 364-366; Rong Xinjiang 栄新江, “Xizhou huihu mounian zaofota gongdeji 西州回鶻某年造佛塔功徳记 [Some Investigations on a Record of Merit of Building a Buddha stūpa in an Unknown Year of the Western Uyghur Kingdom]," in Tujueyu wenxue yanjiu—Geng Shimin jiaoshou bashi huadan jinian wenji 突厥语文学研 究一耿世民教授八十华诞纪念文集 [Studies in Turkic Philology. Festschrift in 
from sources and texts written in different languages, mostly found in Turfan and Dunhuang (敦煌). To my knowledge, ten rulers' titles are preserved as follows:

TABLE 3.2 The titles of the rulers in the West Uyghur Kingdom

Titles

Ruling period

\begin{tabular}{|c|c|}
\hline 溫祿登利邏汨沒密施合俱録毗伽懷健可汗 & $\sim 856 \sim a$ \\
\hline *ulug tägridä kut bulmıš alp külüg bilgä kagan & \\
\hline el bilgä täyri elig & $\sim 954 \sim$ \\
\hline arslan bilgä täyri elig = süyülüg kagan & $\sim 981-984 \sim$ \\
\hline bügü bilgä tägri elig & $\sim 996-1003 \sim \mathrm{b}$ \\
\hline kün ay täyritäg küsänčig körtlä yaruk täyri bügü täyrikänimiz & $\sim 1007-1008 \sim$ \\
\hline $\begin{array}{l}\text { kün ay täyridä kut bulmıš ulug kut ornanmıš alpın ärdämin el tutmiš } \\
\text { alp arslan kutlug köl bilgä tägri han }\end{array}$ & $\sim 1017-1031 \sim$ \\
\hline $\begin{array}{l}\text { kün tägridä kut bulmiš ärdämin el tutmiš alp kutlug ulug bilgä uygur } \\
\text { tägri uygur han }\end{array}$ & $\begin{array}{l}\sim \text { first half of } \\
\text { the } 11 \text { th c. }{ }^{c}\end{array}$ \\
\hline $\begin{array}{l}\text { täyri bügü el bilgä arslan täyri uygur tärkänimiz } \\
\text { 愛登曷哩阿那骨夋里弥施俱録閭蜜伽[ ]聖[ ]可汗 }\end{array}$ & $\begin{array}{l}\sim 1067 \sim \\
?^{\mathrm{d}}\end{array}$ \\
\hline y tägri ?? qut bulmıš külüg köl bilgä [ ] täy[ri] kagan & \\
\hline $\begin{array}{l}\text { kün ay täyrilärdä kut b[u]lm[ı]š [buya]n(kut) ornanmiš alpın } \\
{[\ddot{a}] \text { rdämin el tutmıš üčünč arslan bilqä han(tänri elig tugmıš han) }}\end{array}$ & $?^{\mathrm{e}}$ \\
\hline
\end{tabular}

a The title is documented in Xin Tangshu 新唐書 [New Book of the Tang Dynasty], ed. Ouyang Xiu 歐陽修, Song Qi 宋祁 et al. (Beijing: Zhonghua shuju, 1975), (completed 1060), vol. 217, chapter Huihu 回鶻 [Uyghurs], 6133.

b Rong suggests putting another Uyghur ruler between this and the following one, though there are different opinions, see Rong, "Some Investigations on a Record of Merit," 185; Zieme, "Manichäische Kolophone," 326.

c This ruler is mentioned in the Dunhuang fragment P. 3049 v. It is now preserved in Paris, see мотн по. 5, 42-43, line 8'-11'.

d While Rong assumes his ruling period is around 930, there are other suggestion, see Rong, "Some Investigations on a Record of Merit," 187.

e For a detailed discussion of this ruler, see Umemura, "A Qočo Uyghur King," 364-366. He dates this ruler to after the end of the 1oth century. The readings in the round bracket are suggested by Zieme. See Peter Zieme, "The West Uyghur Kingdom: Views from Inside," Horizons 5.1 (2014): 18. He suggests that this king ruled towards the end of the 1oth century, before 98 o.

Honour of the 8oth Birthday of Professor Geng Shimin], ed. Zhang Dingjing 张定京 and Abdurishid Yakup 阿不都热西提 - 亚库甫 (Beijing: China Minzu University Press, 2009), 184-187. 
The first title differs from the other titles preserved in the fragments excavated in the Turfan and Dunhuang areas, because the Tang emperor planned to give it to the leader of the Uyghurs shortly after they migrated into the Tianshan area. The titles elbilgä tägri elig and arslan bilgä täyrielig = sü̈ülüg kagan appear in a Manichaean text. The title kün tägridä kut bulmıšärdämin el tutmıš alp kutlug ulug bilgä uygur tägri uygur han appears as the addressee of a draft of a letter besides which another draft of a letter and several Manichaean texts are written on the same paper. The remaining rulers are all mentioned in Buddhist texts. The fourth ruler is mentioned because he issued an order. The tenth one appears in a cartouche beside the donor figures in a mural in a Buddhist cave. The eighth ruler's name is mentioned because Uyghur Buddhist donors wanted to share their religious merit with him, which they collected through copying the Buddhist texts. The other rulers' titles all appear in texts that are internally dated through references to the year of a particular king's reign. However, none of those texts appear to be official documents. Therefore, it is unclear whether the titles are complete or abbreviated ones. If we take the fifth, sixth, seventh, ninth, and tenth rulers' titles ${ }^{14}$ as the complete and official titles, they bear in them the elements han or elig 'king,' which are used in the East Uyghur Kaganate. ${ }^{15}$ The continuous use of these titles, together with the celestial objects kün and $a y$, indicates that there was likely no shift in the legitimation strategies of the Uyghur rulers in the period of the West Uyghur Kingdom.

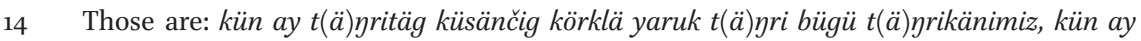
t(ä) yridä kut bulmıš ulug kut ornanmıš alpın ärdämin el tutmıš alp arslan kutlug köl bilgä t(ä)yri han, kün täyridä kut bulmıš ärdämin el tutmıš alp kutlug ulug bilgä uygur täyri uygur han and *ay täyri ?? qut bulmıš külüg köl bilgä [ ] täy [ri] kagan, kün ay täyrilärdä kut $b[u] \operatorname{lm}[\iota] s ̌ s$ buya]n ornanmiš alpın [ä]rdämin el tutmıš üčünč arslan bilgä han.

15 The other title, Idok kut, which became common in the Mongolian period, was probably already borrowed under the ruler of the West Uyghur Kingdom, because it is attested to in a Manichaean text, see, M III, 33-35, No. 15, TM 417, line 19, TM 47 (M 919), lines 9 and 14; R. Rahmeti Arat, "Der Herrschertitel Iduq-qut," Ural-Altaische Jahrbücher 35 (1964), ${ }_{151}^{1-152}$. Those two fragments are now preserved under the same signature, M 919, see Larry V Clark, "The Turkic Manichaean Literature," in Emerging from Darkness: Studies in the Recovery of Manichaean Sources, ed. Paul Mirecki and Jason Beduhn (Leiden, New York, Cologne: Brill, 1997), 133. However, as the above-mentioned titles show, the use of the Uyghur rulers' title, Idok kut, was not common in the period of the West Uyghur Kingdom. This is pointed out by several scholars, see e.g. Umemura, "A Qočo Uyghur King," 361-378; Rybatzki, “Titles of Türk and Uigur Rulers," 258, 268-269. 
In 840, the East Uyghur Kaganate collapsed, and a significant part of the Uyghurs left Mongolia and migrated west. One group settled to the south, around the oasis of Ganzhou (甘州), while another went to the southwest and entered the Eastern Tianshan area. The former group founded the so-called Ganzhou Uyghur Kingdom (middle of the 9th c. to 1028) and the latter the West Uyghur Kingdom. Because of the lack of sources, it is not very clear how and when those two groups formed, or what the nature of their relationship was. This section deals with the West Uyghur Kingdom, although the Ganzhou Uyghur Kingdom, which existed in the same period, cannot be disregarded entirely, even given the lack of sources. ${ }^{16}$

The exact foundation process of the Ganzhou Uyghur Kingdom remains unclear, but it seems to have been established around 89o. The rulers of this kingdom claimed descent from the Yaglakar clan, which was famous as the ruling clan of the East Uyghur Kaganate. ${ }^{17}$ In 898/899, the Tang Dynasty officially acknowledged this kingdom as the Uyghur state and gave an imperial princess in marriage to the Uyghur ruler. ${ }^{18}$ The Ganzhou Uyghur Kingdom appears to have tried to emphasize its position as the successor of the East Uyghur Kaganate. At least for a while, it maintained its nomadic characteristics, even offering the Tang Dynasty its military assistance, as had been the case when the East Uyghur Kaganate provided support for the suppression of An Lushan's Rebellion in the 8th century. ${ }^{19}$ In Central Asia, the Ganzhou Uyghur Kingdom main-

16 Elisabeth Pinks made an important contribution to the research of the Ganzhou Uyghurs with her book. James Russell Hamilton also dealt with this topic in his book. See Elisabeth Pinks, Die Uiguren von Kan-chou in der frühen Sung-Zeit (960-1028) (Wiesbaden: Harrassowitz, 1968); James R. Hamilton, Les oüghours. À l'époque des cinq dynasties d'après les documents chinois (Paris: Collège de France, 1955).

In fact, with the enthronement of the seventh ruler, the ruling clan of this Kaganate changed from the Yaglakar to the Ädiz clan. Even so, the seventh Kagan was adopted by the Yaglakar clan, so that the continuity of the ruling clan was officially kept.

About this topic, see Moriyasu Takao 森安孝夫, “Uiguru to Tonkōウイグルと敦煌 [Uyghurs and Dunhuang]," in Tōzai Uiguru to Chūō Yürashia 東西ウイグルと中央ユーラシ ア [Eastern and Western Uyghurs and Central Eurasia] (Nagoya: Nagoya University publishers, 2015), 307-311. The article was first published in Kōza Tonkō 2 Tonkō no rekishi 講 座敦煌 2 敦煌の歴史 [Series Dunhuang 2 History of Dunhuang], ed. Enok Kazuo 榎一 雄 (Tokyo: Daitōshuppansha, 1980), 297-338. The author himself has expanded the new version.

19 See Tanaka Mineto 田中峰人, “Kanshū Uiguru seiken no sayūyoku taisei 甘州ウイグル 政権の左右翼体制 [Left and Right Wings System of the Ganzhou Uyghurs], in Sogudo kara Uiguru he-Sirukurōdo Tōbu no Minzoku to Bunka no Kōryū- ソグドからウイグル 
tained a close connection with the government in Dunhuang through several intermarriages. Although the religious affiliation of the Ganzhou Uyghurs' ruling house itself is unclear, some royal women, who had marital ties with the Dunhuang rulers, and their children are depicted in the Mogao Caves in Dunhuang as members of the members of Dunhuang's ruling. ${ }^{20}$ Because of its geographical position, situated on the way from Dunhuang to China's central provinces, the Ganzhou Uyghur Kingdom was one of the West Uyghur Kingdom's most critical neighbours. ${ }^{21}$

The early history of the West Uyghur Kingdom also has many lacunae. Shortly after 840, the leader, Pang (龐) Tegin, entered the Karashar area with his followers. ${ }^{22} \mathrm{He}$ asked the Tang Dynasty for its formal endorsement of him as the Uyghur ruler. The Chinese emperor intended to award him the title. The Chinese ambassador, however, was attacked when he was halfway to the Uyghur's royal court, so that the official award does not seem to have been carried out. ${ }^{23}$ Around 851, a local Uyghur leader moved to Turfan, indicating that this area was already under the Uyghur's control by that date. ${ }^{24}$ In 866 , the leader of the Uyghurs based in Beš Balık, Pugu Jun (僕固俊), occupied Turfan and the West Uyghur Kingdom. Pugu Jun seems to have subjugated the ruler in Karashar, but it is unclear whether they belonged to the same clan or not.

ヘーシルクロード東部の民族と文化の交流- [From Sogdians to Uyghurs-Ethinic and Cultural Exchanges in the Eastern Part of the Silk Road], ed. Moriyasu Takao 森安孝夫 (Tokyo: Kyūko shoin, 2011), 267-299; Moriyasu, “Uyghurs and Dunhuang," 311.

$20 \quad$ About this point, see section 5.1 below.

21 Moriyasu points out that the relationship with the Ganzhou Uyghur Kingdom was more important for the Chinese rulers of Dunhuang than that of the Khotan Kingdom. See Moriyasu, "Uyghur and Dunhuang," 320.

In regard to the migration of the Uyghurs and the establishment of the West Uyghur Kingdom, see Moriyasu Takao 森安孝夫, “Uiguru no seisen ni tsuite ウイグルの西遷につい て Nouvel examen de la migration des Ouïgours au milieu du Ixe siècle," in Tōzai Uiguru to Chūō Yürashia 東西ウイグルと中央ユーラシア [Eastern and Western Uyghurs and Central Eurasia], ed. Moriyasu Takao 森安孝夫 (Nagoya: Nagoya University publishers, 2015), 276-298. This article was originally published in the journal Tōyo gakuhō 東方学 報 [Journal of Oriental Studies] 59.1-2 (1977):105-130. The new version was subsequently enlarged by the author. About the West Uyghur Kingdom, see also Zieme, "The West Uighur Kingdom," 1-29.

23 See the first title in table 3.2 in section 2.2 .2 above.

24 Several scholars suggest different interpretations with regard to the question of who placed the local leader in Turfan. See Moriyasu "Uiguru no seisen ni tsuite," 286-287; Rong Xinjiang 栄新江, Guiyijunshi yanjiu—Tang Song shidai Dunhuang lishi kaosuo 歸義軍史硏究一唐宋時代敦煌歴史考察 [The History of Guiyijun一Research on Dunhuang's History in the Tang and Song Period] (Shanghai: Shanghai Chinese Classics Publishing Hourse, 1996), 353-354. 
However, the former's occupation of Turfan means an inevitable change in the rulers' genealogy.

This summary of the foundation of the West Uyghur Kingdom indicates that there was infighting among its leaders, which lasted until a stable rule was established. Furthermore, it is not likely that Pugu Jun was from the Yaglakar clan, the ruling clan of the East Uyghur Kaganate. Although the rulers of the Ganzhou Uygur Kingdom did claim to belong to this clan. ${ }^{25}$ In this situation, the Ganzhou Uyghur rulers presented a competing lineage to the rulers of the West Uyghur Kingdom. It was therefore necessary for Pugu Jun and his successors to present their rule as legitimage internally as well as externally. His target was, first and foremost, the Uyghurs, both those who came with him and those who were already in the Tianshan area during the period of the East Uyghur Kaganate. Hence, the primary issue of legitimation for the ruler of the West Uyghur Kingdom was that the newly established kingdom be regarded as the successor state of the original Uyghur Kaganate in Mongolia.

\subsection{Manichaeism and the Legitimation of the Uyghur Rulers}

Unlike the rulers of the Ganzhou Uyghur Kingdom, the rulers of the West Uyghur Kingdom faced difficulties in claiming genealogical legitimacy, so the significance of other factors that reflected the continuity of rule with the East Uyghur Kaganate grew. One of them was the ruler's role as supporter of Manichaeism, the state religion of the Uyghurs.

It is well known that the Uyghurs kept their Manichaean beliefs for a while after the establishment of the West Uyghur Kingdom and that the rulers demonstrated their role as protectors of the religion as the official creed. According to the Arabic source Kitāb al-Fihrist [The Catalog], written by the Shia scholar and bibliographer Ibn an-Nadim (fl. around the 1oth century), a Uyghur king allegedly made a diplomatic protest against the Khurāsān's ruler, who was supposedly suppressing the Manichaeans under his rule, and threatened him by

25 The Ganzhou Uyghur rulers' claim of descending from the Yaglakar clan also seems to have been acknowledged by the people under the West Uyghur Kingdom's rule. The ambassador who came from that kingdom to Dunhuang wrote the prayer text P. 2988v, in which he refered to the Ganzhou Uyghur Kingdom as "the state of the holy Yaglakar" (OU täni yaglakır eli). Although this prayer text does not contain the date, the discovery site, the Dunhuang cave, indicates that it does not date later than the 11th century, see Moriyasu Takao 森安孝夫, “Uigurugo bunken ウイグル語文献 [Uyghur Literature], " in Kōza Tonkō 6 Tonkō kogo bunken 講座敦煌6敦煌胡語文献 [Series Dunhuang 6 Non-Chinese Literature from Dunhuang], ed. Yamaguchi Zuihō 山口瑞鳳 (Tokyo: Daitō shuppansha, 1985), 22; мотн, No. 15, 83-92, line 27. 
claiming that he would similarly suppress the Muslims in his kingdom. ${ }^{26}$ In exchange for state support, the Manichaean community seemed to have given its support for the legitimation of the West Uyghur Kingdom. One form this support may have taken is Manichaean hymns used in official ceremonies. In the Berlin Turfan Collection, altogether six hymns and praises in Middle Persian and Old Uyghur have been identified as dedicated to the Uyghur rulers or their kingdom. ${ }^{27}$ Among them is also the so-called Enthronement Hymn M 919, indicating that some of them were probably produced for use in official ceremonies.

The expansion and completion of the ancestral legend, i.e. the Bokug Khan Legend, is another of the Manichaean contributions towards the legitimation of the rulers of the West Uyghur Kingdom. This legend is mainly documented in later Persian and Chinese sources dating from the Mongolian period (13th14th c.). In this legend, the Uyghur ancestor, Bokug Khan, is described as a supernatural being. Several Manichaean elements play a significant role, like the tree of life, the light from Heaven, and the white robed person. ${ }^{28}$ The introduction of Manichaeism in the East Uyghur Kaganate probably served as the impetus for the creation of this legend. ${ }^{29}$ Because the legend mentions the migration of the Uyghurs in the westward direction, the final version was first established in the period of the West Uyghur Kingdom. This legend explains how the earliest Uyghur ancestor was born and how he won his lordship in a

26 About the English translation of the corresponding sentences, see Bayard Dodge, The Fihrist of al-Nadim: A Tenth-Century Survey of Islamic Culture (New York: Columbia University Press, 1970), 802-803.

27 See vord 13,16, no. 297 (U 31), no. 334 (Ch/U 3917), no. 344 (U 5362), no. * 348 (*TM 176), no. $35^{2}$ (M 919). For the Middle Persian hymn, M 43 see Friedrich W.K. Müller, "Handschriften-Reste in Estangelo-Schrift aus Turfan II," Abhandlungen der preußischen Akademie der Wissenschaften, phil.-hist. Klasse 2 (1940): 78-79. Two further fragments U 141 and U 184 are maybe also dedicated to the Uyghur king. See voHD 13,16, no. 298 (U 141) and no. 300 (U 184). In addition, the ruler is the topic of the three fragments. See voHD 13,16, no. 339 (M 111 II ), no. 343 (M 525a,b) and no. 384 (U 251a,b). For an overview on the Old Uyghur Manichaean literature, see Clark, "The Turkic Manichaean Literature," 121-141. There he listed 27 enthronements/installation hymns, benedictions or eulogies, among which 17 settled on the subject matter of rulers or a realm. See Clark, "The Turkic Manichaean Literature," 133-134, no. 119-134. However, Jens Wilkens later suggested different identifications for some of these texts. See voHD 13,16.

28 Several scholars investigated this legend. For detailed information about sources, the summary, and previous studies, see e.g. Yukiyo Kasai, "Ein Kolophon um die Legende von Bokug Kagan,” Nairiku ajia gengo no kenkyū 内陸アジア言語の研究 [Studies on the Inner Asian Languages] 19 (2004): 9-14.

29 As mentioned in section 2.1.2. above, there was a change of the ruling clans with the enthronement of the seventh ruler. Thus, it could also be seen as a motivation for producing this legend. 
Manichaean context. Thus, the rulers of the West Uyghur Kingdom could claim their connection to those of the East Uyghur Kaganate through representing it as their own ancestral legend.

These factors indicate the strong commitment of the Uyghur rulers to Manichaeism, the state religion of both the East Uyghur Kaganate and the West Uyghur Kingdom, and the latter's official support for the legitimation of the former.

Official Treatment of the Religious Communities in the West Uyghur Kingdom

\subsection{Political and Financial Support for the Religious Communities}

Manichaeism kept its status as the state religion of the West Uyghur Kingdom, however the influence of Buddhism gradually became stronger. Eventually, during the second half of the 1oth century or at the beginning of the 11th century, Buddhism deposed Manichaeism as the dominant religion of the Uyghurs. ${ }^{30}$ Even so, both religions co-existed under Uyghur rule for a certain period thereafter. Before discussing the role of Buddhism in Uyghur legitimation strategies is, I address how the Uyghur rulers dealt with both religions during this period of co-existence in their kingdom.

The so-called "Order Concerning the Economy of Manichaean Monasteries," found in Turfan, attests to the fact that the Uyghur rulers generally involved themselves in the active management of the religious communities in their kingdom. ${ }^{31}$ This partially preserved text bears the red-colored Chinese seal of the Uyghur chancellor imprinted eleven times, so we know that it was

30 See e.g. Moriyasu Takao 森安孝夫, “Toruko bukkyō no genryū to ko torukogo butten no shutsugen トルコ仏教の源流と古トルコ語仏典の出現 L'origine du Bouddhisme chez les Turcs et l'apparition des textes bouddhiques en turc ancien," in Tōzai Uiguru to Chūō Yūrashia 東西ウイグルと中央ユーラシア [Eastern and Western Uyghurs and Central Eurasia], ed. Moriyasu Takao 森安孝夫 (Nagoya: Nagoya University publishers, 2015), 618-644. The article was first published in Shigaku zasshi 史学雑誌 [Journal of Historical Studies] 98.4 (1989): 1-35; Moriyasu, "Uiguru = Manikyō shi," 147-174; Moriyasu, Die Geschichte des uigurischen Manichäismus, 174-209; Xavier Tremblay, "The Spread of Buddhism in Serindia: Buddhism among Iranians, Tocharians and Turks before the 13th century," in The Spread of Buddhism, ed. Ann Heirman and Stephan Peter Bumbacher (Leiden and Boston: Brill, 2007), 108-114.

Moriyasu made the edition of this text, with detailed philological and historical investigations, see Moriyasu, "Uiguru = Manikyō shi," 35-126; Moriyasu, Die Geschichte des uigurischen Manichäismus, 39-147. 
issued by the royal court of the West Uyghur Kingdom. ${ }^{32}$ According to the contents of the document, the Uyghur royal court promised official financial support to the Manichaean monasteries in different ways, and the detailed rules for the management of the Manichaean monasteries were set out. ${ }^{33}$

While regulations were also made for the Buddhist community, they were probably less detailed than those for the Manichaeans. A fragment that possibly dates to the pre-Mongolian period promises tax exemption for a certain Buddhist monastery located in Murtuk. ${ }^{34}$ This document has a red seal that shows significant similarities to that of the above-mentioned Manichaean document. Thus, it was likely also issued by the court of the West Uyghur Kingdom.

\subsection{Uyghurs' Religious Shifts and Political and Financial Support}

These examples make it clear that the Uyghur rulers involved themselves in the management of the religious communities. Now, it is an essential question: How was the religious shift from Manichaeism to Buddhism reflected in the Uyghur rulers' actions?

The contents of two fragments in particular are worth considering. The first fragment, M 112v, reports the destruction of a Manichaean monastery, which was ordered by the Uyghur king in 983. This order was given so that a new Buddhist monastery could be built, and the Uyghur prince personally carried out the construction. ${ }^{35}$ It indicates that - already by the middle of the 1oth century - the Uyghur ruler was ready to demonstrate his favour for the Buddhist community in such a radical way.

32 See Moriyasu, "Uiguru = Manikyō shi," 127-128; Moriyasu, Die Geschichte des uigurischen Manichäismus, 149-151.

33 The rules for managing the monasteries were necessary because the Manichaean clergy had to follow a strict regime of rules, something which made the management of the monasteries on their own accord a tricky issue. At least part of those rules seems to have been enacted because reports about them are preserved in several fragments. See Moriyasu, "Uiguru = Manikyō shi," 83-87; Moriyasu, Die Geschichte des uigurischen Manichäismus, 103-108.

34 This fragment was dealt with by Zieme as Text B in his article, Peter Zieme, "Uigurische Steuerbefreiungsurkunden für buddhistische Klöster," Altorientalische Forschungen 8 (1981): 254-258. About the dating, see also Moriyasu, "Uiguru = Manikyō shi," 134, fn. 17; Moriyasu, Die Geschichte des uigurischen Manichäismus, 158, fn. 17.

See Moriyasu, "Uiguru = Manikyō shi," 147-150; Moriyasu, Die Geschichte des uigurischen Manichäismus, 174-178; Takao Moriyasu, "History of Manichaeism among the Uighurs from the 8th to the 11th Centuries in Central Asia," in Siruku rōdo to sekaishi シルクロード と世界史 [World History Reconsidered through the Silk Road], ed. Moriyasu Takao 森安 孝夫 and Sakajiri Akihiro 坂尻彰宏 (Toyonaka: Osaka University The 21st Century COE Program Interface Humanities Research Activities 2002, 2003), 86-9o. 
On the other hand, the second fragment, *U 9271, contains a list on the verso of the official income and expenditure for both Buddhist and Manichaean monasteries. This fragment indicates that the Uyghur rulers tried to give support to both religious communities. Dai Matsui assumes that this ledger was made specifically for the temple ruin $\alpha$ in Kočo, which was initially a Manichaean sanctuary. Because this temple was turned into a Buddhist temple in 1008 , the account book should be dated to that period as well. ${ }^{36}$ If his assumption is correct, the Manichaean monks were still allowed to stay in that temple, or perhaps near it, after it was handed over to the Buddhists. According to the ledger, the number of Manichaean monks was less than that of Buddhist monks, and the different items given to them are described as pure 'charity.' In contrast, items for the Buddhist community are described to as 'king's charity,' and were much greater than those given to the Manichaeans. Thus, it is clear that Buddhism was favoured by the ruler. However, it does not seem that the Uyghur rulers immediately cut off their support to the Manichaean community. ${ }^{37}$

${ }_{3}$ Dai Matsui, "An Old Uigur Account Book for Manichaean and Buddhist Monasteries from Tempel $\alpha$ in Qočo," in Zur lichten Heimat. Studien zu Manichäismus, Iranistik und Zentralasienkunde in Gedenken an Werner Sundermann, ed. Team "Turfanforschung" (Wiesbaden: Harrassowitz, 2017), 409-420; Matsui Dai 松井太, "Koshō kojō jiinato $\alpha$ no manikyōto to bukkyōto 高昌故城寺院址 $\alpha$ のマ二教徒と佛教徒 [Manichaeans and Buddhists in Coexistence at Temple $\alpha$ of Qočo]," in Ōtani tankentai shūshū saiiki kogo bunken ronsō. Bukkyō, Manikyō, Keikyō 大谷探檢隊収集西域胡語文獻論叢: 佛教・マ 二教・景教 [Essays on the Manuscripts Written in Central Asian Languages in the Otani Collection: Buddhism, Manichaeism, and Christianity], ed. Takashi Irisawa 入澤孝 and Kōichi Kitsudō 橘堂晃一 (Kyoto: Research Institute for Buddhist Culture/Research Center for World Buddhist Cultures, Ryukoku University, 2017), 71-86. Regarding the change the temple that is now known as the ruin $\alpha$, see e.g. Werner Sundermann, "Completion and Correction of Archaeological Work by Philological Means: The Case of the Turfan Texts," in Histoire et cultes de l'Asie Centrale préislamique. Sources écrites et documents archéologiques, ed. Paul Bernard and Franz Grenet (Paris: Centre National de la Recherche Scientifique, 1991), 286-288.

37 In addition, Yoshida supposes that the Manichaeans of the West Uyghur Kingdom shifted their essential Bema festival days because they wanted to have the participation of the members of the Uyghur royal family, who in the 1oth century were increasingly attracted to joining the Buddhist festival that took place on the same day. See, Yutaka Yoshida "Buddhist Influence on the Bema Festival," in Religious Themes and Texts of Pre-Islamic Iran and Central Asia. Studies in Honour of Professor Gherardo Gnoli on the Occasion of His 65 th Birthday on 6th December 2002, ed. Mauro Maggi et al. (Wiesbaden: Reichert, 2003), 453-458. If his assumption is correct, the Uyghur royal family sent its members to the important festivals of both the Buddhist and the Manichaean communities. This again shows that the Manichaeans tried to get the Uyghur's royal support, and this effort seems to have been successful to some degree. So the Uyghur royal power supported not only the Buddhists but also the Manichaean communities, at least during a certain period. On 
Whether these actions reflect a partial preference for Buddhism over Manichaeism or not, they show that the Uyghur rulers involved themselves deeply in the regulation of both Manichaean and Buddhist communities. As the fragment $\mathrm{M} 112 \mathrm{v}$ shows, some rulers were ready to express their religious preference in a radical manner. However, the last quoted ledger indicates that in some cases and at certain times the Uyghur rulers tried to maintain some equilibrium between the two religious communities. It was not only due to the religious tendency of the rulers per se, but was most likely also due to their political judgment.

\subsection{Political Treatments of the Different Buddhist Groups}

Such different treatment was even applied within the Buddhist community in Turfan. In the introduction of Buddhism to the Uyghurs, mainly Tocharians and Chinese Buddhists played important roles, although the latter's influence was increasingly dominant over time. ${ }^{38}$ After Buddhism became the dominant religion among the Uyghurs, the rulers appointed Buddhist monks to government positions. The particular circumstances of this are still debated. ${ }^{39}$ The Chinese letter P. 3672 bis reports one case of such an appointment. It was sent by a high-ranking Uyghur monk from Turfan to Dunhuang during the second half of the 1oth century. ${ }^{40}$ It shows the Uyghur monk's specific connection to

this topic, see also Moriyasu Takao 森安孝夫, “Nishi Uiguru ōkoku ni okeru manikyō no suitai to bukkyō no taitō 西ウイグル王国におけるマ二教の衰退と仏教の台頭 [The Declination of Manichaeism and the Rise of Buddhism in the West Uyghur Kingdom]," in Tōzai Uiguru to Chūō Yūrashia 東西ウイグルと中央ユーラシア [Eastern and Western Uyghurs and Central Eurasia], ed. Moriyasu Takao 森安孝夫 (Nagoya: Nagoya University publishers, 2015), 590-617.

38 Since his first article in 1989 , Moriyasu deals with this topic in several articles. For the most recent version, see Moriyasu, "Toruko bukkyō no genryū to ko torukogo butten no shutsugen," 618-644.

39 Concerning these discussions, see e.g. Takao Moriyasu, "Chronology of West Uighur Buddhism-Re-examination of the Dating of the Wall-paintings in Grünwedel's Cave No. 8 (New: No. 18), Bezeklik" in Aspects of Research into Central Asian Buddhism. In memoriam Kōgi Kudara, Silk Road Studies XVI, ed. Peter Zieme (Turnhout: Brepols publishers, 2008), 191-227. The Japanese version was published in Bukkyō gaku kenkyū 仏教学研究 [Studies in Buddhism] 62-63 (2007): 1-45, and again in Moriyasu's book in 2015. There are few changes in the contents of these versions. See also Jens Wilkens, "Buddhism in the West Uyghur Kingdom and Beyond," in Transfer of Buddhism Across Central Asian Networks (7th to 13th Centuries), ed. Carmen Meinert (Leiden, Boston: Brill, 2016), 246-249.

The letter was published by Moriyasu with philological and historical commentaries. For the newest version, see Moriyasu Takao 森安孝夫, “Tonkō to Nishi Uiguru ōkoku一Torufan kara no shokan to okurimono wo chūshin ni一敦煌と西ウイグル王国一トウルファ ンからの書簡と贈り物を中心に一 [Dunhuang and the West Uyghur Kingdom—The Historical Background of the Letter, $\mathrm{P}_{3672}$ Bis, Sent from Turfan-]," in Tōzai Uiguru to 
the Chinese Buddhist community in Dunhuang at that time. According to that letter, the Uyghur monk received a golden seal from the ruler of the West Uyghur Kingdom. The monk is known to have been the head of many Chinese and non-Chinese monks. This indicates that in the above period, the monk, who had a close relationship with Chinese Buddhism, was placed in a highranking position by the Uyghur ruler. ${ }^{41}$

This document seems to indicate that the Uyghur rulers had an apparent preference for Chinese Buddhism already in the second half of the 1oth century, although the Tocharian influence was still present. However, Kōichi Kitsudō recently pointed out that on the wall in Mogao Cave 148 in Dunhuang, as well as in Cave 20 in Bezeklik, several Tocharian monks were painted with accompanying Brāhmī inscriptions, which inform us that these monks held the golden seal, like the monk in the above-mentioned Chinese letter. ${ }^{42}$ Bezeklik Cave 20 was probably made during the 12 th century. Of course, it is an open question whether this wall painting represents contemporary monks or historically important ones. However, at least in that period, it was still known that there were monks who followed the tradition of Tocharian Buddhism and who were given high-ranking government positions in the West Uyghur Kingdom. Also, in Bezeklik Cave 2o, the monks appear dressed in not only Tocharian clothes, but also in Chinese clothes. It seems that those two Buddhist communities were recognised as important ones on the same level, or that at least that was what was intended.

The Uyghur rulers' simultaneous support for both the Manichaean and Buddhist communities (for a while at least) and the recognition of both Tocharian and Chinese Buddhist traditions as on the same level, indicate that the Uyghur rulers intended to maintain a balance between the different religious

ChūōYūrashia 東西ウイグルと中央ユーラシア [Eastern and Western Uyghurs and Central Eurasia], ed. Moriyasu Takao 森安孝夫 (Nagoya: Nagoya University publishers, 2015), 336-337. The article was first published in Tōhō gaku 東方学 [Eastern Studies] 74 (1987): $5^{8-74 .}$

41 Although the monk in question wore an Uyghur title, Moriyasu assumes that he was Chinese, considering his command of Chinese letter writing. Cf. the renewed version, Moriyasu, "Chronology of West Uighur Buddhism," 208.

42 See Kitsudō Kōichi 橘堂晃一, "Bezekuriku sekkutsu kuyō bikuzu saikō-Tonkō bakkōkutsu no meibun wo tegakari to shite一 ベゼクリク石窟供養比丘図再考一敦煌莫高 窟の銘文を手がかりとして— [Reconsideration of the Monk's Donor Portrait in the Bezeklik Cave-According to the Inscription in the Dunhuang Cave-]," in Ajia bukkyō bijutsushū. Chūō Ajia I. Gandāra Tōzai Torukisutan アジア仏教美術論集中央アジアI ガンダーラ〜東西トルキスタン [Essays on the Asian Buddhist Arts. Central Asia I. Gandhara Eastern and Western Turkestan], ed. Miyaji Akira 宮治昭 (Tokyo: Chūō kōron bijutsu shuppan, 2017), 523-550. 
communities within their territory. This leads us to conclude that the government probably carried out specific religious policies, while at the same time tried to control and support those different communities.

As described in section 3.2, the rulers of the West Uyghur Kingdom acted as the protectors of Manichaeism, and the religion acknowledged that role of the rulers through hymns, some of which were performed in official ceremonies. Furthermore, section 4 shows that in domestic affairs, the Uyghur rulers gave their support to both Manichaean and Buddhist monasteries, and tried to keep a balance between the different religious communities. From these facts, it is likley that along with the shift in the Uyghur's belief, the role of Manichaeism in the legitimation of the rulers was taken over by Buddhism.

\subsection{Buddhist Legitimation in the Neigbouring Oasis States}

Takatoshi Akagi made a major contribution to the field of Buddhist legitimation in Central Asia, including the West Uyghur Kingdom. Based on the Dunhuang materials, he pointed out that in the 1oth century, some of the Guiyijun (851-1036?, 歸義軍, Return-to-Allegiance Army) rulers in Dunhuang positioned themselves as Buddhist kings, by calling themselves 'cakravartin', or 'bodhisattva king,' and vigorously supported large-scale Buddhist events and the creation of Buddhist votive-caves. These activities coincided with changes in the political situation in the region. At that time, Dunhuang could no longer rely on the authority of the Chinese emperors, mostly because of Tang Dynasty's fall, and the governors there increasingly became independent. Thus, they had the need to legitimate their rule anew. In Akagi's opinion, the elevation of the rulers to the status of Buddhist or bodhisattva kings can not only be observed within the Guiyijun regime, but also in the Khotanese Kingdom and in the West Uyghur Kingdom during the same period. ${ }^{43}$

43 See Akagi Takatoshi 赤木崇敏, “Jusseiki Tonkō no ōken to tenrijō’ō kan 十世紀敦煌の 王権と転輪聖王 [Kingship and the Idea of the Cakravartin in 1oth Century Dunhuang],” Tōyōshi kenkyū 東洋史研究 [Oriental Researches] 69.2 (2010): 233-252; “Konrin jō’ō kara bosatsu no jinō he-Jusseiki Tonkō no ōken to bukkyō- 金輪聖王から菩薩の人王一-1 O世紀敦煌の王権と仏教- [From Gold Wheel-Turning Kings to Bodhisattva Human Kings-The Royal Power and Buddhism in Dunhuang in the 1oth Century-]," Rekishi no riron to kyōiku 歴史の理論と教育 [Historical Theories and Educations] 139 (2013): 3-17. The Tangut emperors were also equated with cakravartin or dharmaräja, see e.g. Ruth W. Dunnell, The Great State of White and High. Buddhism and State Formation in EleventhCentury Xia (Honolulu: University of Hawai'i Press, 1996), 36-63. 
The governors of the Guiyijun and their family members, including their Khotanese and Ganzhou Uyghur wives, are well represented among the donor figures in both the Mogao and Yulin Caves. ${ }^{44}$ Thus, their presence demonstrates their power and diplomatic alliance with Dunhuang. However, whether the Khotanese and Uyghur rulers adopted the equalization of rulers with Buddhist kings is open to question. Unlike in Dunhuang, the political situation for the Khotanese and Uyghur rulers did not undergo any significant changes during the 1oth century. ${ }^{45}$ Furthermore, the written sources that might prove that the Khotanese and Uyghur rulers also used the same legitimation strategy as the rulers in Dunhuang have all been found in Dunhuang. ${ }^{46}$ Thus it is possible that those sources reflect the equalization of the rulers in Dunhuang with Buddhist kings.

\subsection{Uyghur Rulers in Buddhist Paintings and Eulogies}

Some Uyghur donor portraits painted in caves or on banners have been referred to as Uyghur rulers' portraits. However, they mostly seem to be the portraits of royal family members or high-ranking Uyghurs, and only a few of them can be identified as ruler portraits, based on the inscriptions accompanying them. ${ }^{47}$ Furthermore, many of those portraits are in the Mogao Caves at Dun-

44 See e.g. Akagi Takatoshi 赤木崇敏, “Sōshi kigigun setsudoshi jidai no Tonkō sekkutsu to kuyōnin zō 曹氏歸義軍節度使時代の敦煌石窟と供養人像 [Dunhuang Caves and Donor Figures in the Period of Guyijun of the Cao Family]," Tonkō shahon kenkyū nenpō 敦煌寫本研究年報 [The Annual Reports on the Research of the Dunhuang Manuscripts] 10 (2016): 285-308; Moriyasu "Uyghur and Dunhuang," 318-322; Lilla RussellSmith, Uyghur Patronage in Dunhuang. Regional Art Centres on the Northern Silk Road in the Tenth and Eleventh Centuries (Leiden, Boston: Brill, 2005), 228-229. About the political change of the West Uyghur Kingdom, see section 3.

46 See, Akagi, "Kingship and the Idea," 250-253; "From Gold Wheel-Turning Kings," 9-11. There, altogether eight texts which mention the Khotanese kings are listed. While the fragment P. T. 1120, IOL Khot S 22 (Ch.xl.oo2), P. 2739 and P. 2958 mention the Khotanese kings as the addressers, the manuscript P 4099, IOL Khot S 47 (Ch.i.oo21 b.a), IOL Khot S 21 (Ch.i.oo21 a.a), IOL Khot S 74/3 (Ch.oo274) and P 2739 are Buddhist eulogies, colophons, and prayer texts. None of them derive from Khotanese kings or their royal court, and therefore do not prove that the Khotanese kings themselves used the above-mentioned legitimation strategy. In regard to the Uyghur kings, only one Chinese prayer text, S. 6551, mentions an Uyghur king as the incarnation of a bodhisattva.

As far as I know, they are in the room S 105 in Beš Balık and the Mogao Cave 409 in Dunhuang. In regard to $S$ 105, see, Umemura, “A Qočo Uyghur King," 364-366. For Cave 409, see e.g. Matsui Dai 松井太, "Tonkō shosekkutsu no uigurugo daiki meibun ni kansuru sakki (2) 敦煌諸石窟のウイグル語題記銘文に關する劄記(二) [Notes on the Uyghur Inscriptions in Dunhuang Caves]," Jinbun shakai ronsō (Jinbun kagaku hen) 人文社会論 叢(人文科学篇) [Studies in the Humanities, Cultural Sciences] 32 (2014): 27-30. Besides, the portrait in the Western Thousand Buddha Cave (Chin. Xi Qianfodong 西千佛 
huang. During the 11th century, Dunhuang came under the control of the Uyghurs connected with the West Uyghur Kingdom. ${ }^{48}$ Thus, those portraits were possibly produced by these Uyghurs, who simply followed local customs. It is, therefore, likely that the donors' portraits were not so effectively utilised as a means to represent the rulers in Buddhist contexts in Turfan, as was common in Dunhuang.

Among the Buddhist eulogies in Old Uyghur, which are considerably more numerous than Manichaean ones, there are only a few that directly mention Uyghur rulers. In contrast to the Manichaean ones-which were often dedicated to the rulers and their kingdom, and were probably also used in official ceremonies - only a few Buddhist eulogy texts feature the Uyghur rulers and their kingdom as their main topic. ${ }^{49}$ Furthermore, they are mostly written in

洞) 13 (former Cave 16) is often mentioned as an Uyghur king, see Dunhuang yanjiuyuan 敦煌硏究院 [Dunhuang Academy], Zhongguo shiku. Anxi Yulin ku 中国石窟安西榆林 窟 [Chinese Caves: Anxi Yulin Caves] (Tokyo: Heibonsha, 1990), 239. Concerning the Manichaean paintings, the same investigation ought to be carried out. However, the number of preserved Manichean paintings is really very small, and some of them were probably covered by newer Buddhist paintings. One example of this can be seen in Cave 38. Cf. Moriyasu "Uiguru = Manikyō shi," 7-27; Moriyasu, Die Geschichte des uigurischen Manichäismus, 2-28.

48 See, Moriyasu Takao 森安孝夫, “Sashū Uiguru shūdan to Nishi Uiguru ōkoku 沙州ウイ グル集団と西ウイグル王国 [The Shazhou Uyghurs and the West Uyghur Kingdom],” in Tōzai Uiguru to Chūō Yürashia 東西ウイグルと中央ユーラシア [Eastern and Western Uyghurs and Central Eurasia], ed. Moriyasu Takao 森安孝夫 (Nagoya: Nagoya University publishers, 2015), 355-374. The article was originally published in Nairiku ajiashi kenkyū 内陸アジア史研究 [Inner Asian Studies] 15 (2000): 21-35; Takao Moriyasu, "The Sha-chou Uighurs and the West Uighur Kingdom," Acta Asiatica 78 (2000): 28-48. As summarised by Moriyasu, there are still different opinions on how strong the Uyghur's control on Dunhuang was at that time.

49 Zieme has worked intensively on the Buddhist alliteration eulogies in Old Uyghur, see e.g. Peter Zieme, Die Stabreimtexte der Uiguren von Turfan und Dunhuang: Studien zur alttürkischen Dichtung (Budapest: Akadémiai Kiadó, 1991); Peter Zieme, "La poésie en turc ancien d'après le témoignage des manuscrits de Turfan et Dunhuang," Comptes Rendus de l'Académie des Inscriptions et Belles-Lettres 149.5 (2005): 1145-1168. As far as I know, the following Buddhist eulogies are dedicated to the Uyghur rulers and their kingdom: $\mathrm{Ch} / \mathrm{U}$ $6691+\mathrm{Ch} / \mathrm{U} 6687 ; \mathrm{Ch} / \mathrm{U} 7542 ; \mathrm{Ch} / \mathrm{U} 775^{\circ}+\mathrm{Ch} / \mathrm{U} 7540 ; \mathrm{Ch} / \mathrm{U} 7547$, Ch/U 6849 (T II Y 58 ${ }_{6}$ ), $\mathrm{Ch} / \mathrm{U} 7154$ (T III 1138), SI D/17, U 1864 (T II Y 22). About the first three praises, see BT xxxVIII, 176-181, 174-175, 208-209; Peter Zieme, "Remarks on Old Turkish Topography," in Languages and Scripts of Central Asia, ed. Shirin Akiner and Nicholas Sims-Williams (London: Routledge, 1997), 45-51; Peter Zieme, "Some Notes on the Ethnic Name Tayut (Tangut) in Turkic Sources," in Tanguty v Central'noj Azii. Sbornik Statej v Chest" 8o-letija Professora E. I. Kychanova, ed. Irina Fedorovna Popova (Moskva: Bostochnaja Literatura, 2012), 461-468; Peter Zieme, "Eine Eloge auf einen uigurischen Bäg," Türk Dilleri Araştırmaları 3 (1993): 271-284. About SI D/17, see Lilia Yusufzhanovna Tuguševa, "Ein Fragment eines frühmittelalterlichen uigurischen Textes," in Turfan, Khotan und 
the cursive script, which indicates that they were possibly copied during the Mongolian period. Although they could in theory have been produced during the pre-Mongolian period, none of them indicate the possibility that they were used in official functions.

Even so, one eulogy, SI D/17, requires special attention. It is written in semiblock script in the horizontal mode, so its production can be safely dated to the 1oth century. The eulogy relates to the above-mentioned ancestral legend of the Uyghurs. As discussed above, this ancestral legend was first completed in the West Uyghur Kingdom under a Manichaean influence. Thus SI D/17 refers to that legend in its early Buddhist adaptation. In the Old Uyghur Annals, written during the Mongolian period in the cursive script, the name of the ancestor, Bokug Khan, is also mentioned. Hence, we know that this Buddhist version predates the Old Uyghur Annals version, and was in vogue until the Mongolian period. ${ }^{50}$ However, the other sources from the Mongolian period that preserve this legend do not mention the Buddhist version of the Bokug Khan legend. Especially the Persian Tärīh-i Ğahāngušăy [The History of the World Conqueror (i.e. Činggiz Khan)] written by 'Alā ad-Dīn 'Ața-Malik Ğuwaynī (ca. 12261283) is important for thinking about the circumstances in which the Buddhist version of the legend was known. The author of that Persian book acted as an important political figure in Khurāsān under Mongolian rule. He also visited the Mongolian Great Khan's court in Karakorum on several occasions. ${ }^{51}$ Thus he probably had a good chance to collect information on different ethnic

Dunhuang: Vorträge der Tagung "Annemarie von Gabain und die Turfanfroschung", veranstaltet von der Berlin-Brandenburgischen Akademie der Wissenschaften in Berlin (9.12.12.1994), ed. Ronald E. Emmerick et al. (Berlin: Akademie Verlag, 1996), 353-359; Oda Juten 小田壽典, “Buku han densetsu no uigurugo bukkyō shahon ichi danpen- Tugusheva happyō ni yosete ブク・ハン伝説のウイグル仏教写本一断片ートウグーシェヴア 発表によせて [An Uyghur Buddhist Fragment of Bokug Han Legend-To L. Ju. Tuguševa's Lecture]," Aidai Shigaku-Nihonshi, Ajiashi, Chirigaku 愛大史学-日本史・ア ジア史・地理学 [Aichi University Historical Journal: Janapese History, Asian History, Geography] 7 (1998): 57-67. In addition, one praise Ch/U 7613+Mainz 713(T II Y 58) is dedicated to the Bäg of Kočo and his wife, see e.g. Jens P. Laut and Peter Zieme, "Ein zweisprachiger Lobpreis auf den Bäg von Kočo und seine Gemahlin," in Buddhistische Erzählliteratur und Hagiographie in türkischer Überliferung, ed. Jens P. Laut and Klaus Röhrborn (Wiesbaden: Harrassowitz, 1990), 15-36, see BT XXXVIII, 182-191. See also Wilkens, "Buddhism in the West Uyghur Kingdom," 244-245.

50 See Tieshan Zhang and Peter Zieme, "A Memorandum about the King of the On Uygur and His Realm," Acta Orientalia Academiae Scientiarum Hungaricae 64.2 (2011): 135-145; Zieme, "The West Uyghur Kingdom," 14-15.

$5^{1} \quad$ John Andrew Boyle briefly summarised his life, see John A. Boyle, trans., Genghis Khan. The History of the World Conqueror (Manchester: Manchester University Press, 1958), xxvii-xxxvii. 
groups, including the Uyghurs, who were already Mongolian subjects at that time. Therefore, the Uyghur's ancestral Bokug Khan legend — which he documented in his book — can be seen as the standard version known at the Mongolian court. ${ }^{52}$ It indicates that in that period, the original version of the legend which contains many Manichaean elements, still seems to have been known as the Uyghurs' ancestral legend, even among the Mongols, who were the suzerain of the Uyghurs, although the Buddhists already adopted it in the pre-Mongolian period.

\subsection{Uyghur Rulers and Their Activities in Other Buddhist Texts}

The eulogies are not the only place where the rulers demonstrated their power in Buddhist contexts. The Guiyijun governors appear in various prayer texts (Chin. yuanwen 願文) that often report the Buddhist activities carried out by the governors as official ceremonies. ${ }^{53}$ Furthermore, the Tibetan manuscripts from Dunhuang inform us that certain Buddhist texts were systematically copied in Tibetan for the Tibetan emperors who ruled Dunhuang. ${ }^{54}$ In the Tangut Empire, the translation project of Buddhist texts was carried out by order of the emperors. ${ }^{55}$

Up to now, however, no clear-cut traces of such activities have been found in any Buddhist texts from the West Uyghur Kingdom. ${ }^{56}$ As several fragments and inscriptions show, Uyghur laymen and laywomen of the nobility, including

$5^{2} \quad$ The possibility that this part was re-edited after the introduction of Buddhism into the Mongolian court under Khubilai's rule (r. 126o-1294) cannot be completely denied. Because of the geographical and political distance, it is, however, not very likely that such a measure was seriously carried out.

53 About those texts, see Akagi, "Kingship and the Idea of the Cakravartin," 243; Akagi, "From Gold Wheel-Turning Kings to Bodhisattva Human Kings," 7 .

54 See e.g. Kazushi Iwao, "The Purpose of Sūtra Copying in Dunhuang under the Tibetan Rule," in Dunhuang Studies: Prospects and Problems for the Coming Second Century of Research, ed. Irina Popova and Liu Yi (St. Petersburg: Slavia, 2012), 102-105.

55 See e.g. Nishida Tatsuo 西田龍雄, “Seika no bukkyō ni tsuite 西夏の仏教について [On Tangut Buddhism]," in Seika ōkoku no gengo to bunka 西夏王国の言語と文化 [Language and Culture of Tangut Kingdom], ed. Nishida Tatsuo 西田龍雄 (Tokyo: Iwanami shoten, 1997), 403-437. The article was first published in Nanto bukkyō 南都仏教 [Journal of the Nanto Society for Buddhist Studies] 22 (1969): 1-19; Shi Jinpo 史金波, Xixia fojiao shilïe 西夏仏教史略 [A Brief History of Tangut Buddhism] (Yinchuan: Ningxia renmin chubanshe, 1988), $5^{8-72}$.

56 The question of whether the Uyghurs created a Buddhist canon is also an important topic that has been discussed many times. Neither its production nor its existence can be documented in any surviving texts. For the details on this issue, see e.g. Jens Wilkens, "Hatten die alten Uiguren einen buddhistischen Kanon?" in Kanonisierung und Kanonbildung in der asiatischen Religionsgeschichte, ed. Max Deeg et al. (Vienna: Austrian Academy of Sciences, 2011), 345-378. 
members of the royal family, acted as donors. However, in these sources, the Uyghur rulers themselves do not appear as donors. ${ }^{57}$ Most notable is the absence of Uyghur rulers in donor colophons. These colophons were commonly written after the same template, and were partly developed on the basis of Chinese prayer texts, the majority of which have been found in Dunhuang. ${ }^{58}$ Both Chinese prayer texts and Old Uyghur colophons express the dedications of religious merit by the donors. Moreover, the people to whom the merit is dedicated are mentioned according to their social rank. ${ }^{59}$ In many Chinese prayer texts, the Guiyijun rulers are usually mentioned at the top of this list. ${ }^{60}$ This indicates that the legitimation strategy of those rulers functioned successfully in Buddhist contexts, and was also acknowledged by the inhabitants in Dunhuang. However, the Old Uyghur colophons dating from the period of the West Uyghur Kingdom do not mention those rulers at all, with a single exception, namely the preface of the Hami version of Maitrisimit [Meeting with the Maitreya], which was written in $1067 .{ }^{61}$ Thus, the dedication of religious merit to the rulers does not seem to have become a fixture in Old Uyghur colophons

57 Moriyasu, who investigated the inscriptions and wall paintings in Cave 8 in Bezeklik, assums that this cave-temple was bestowed by the Uyghur king. See Moriyasu, "Chronology of West Uighur Buddhism," 199-200. However, the inscription he uses for his argument does not mention who presented the temple. As the so-called Stake Inscriptions show, several temples were donated by members of the royal family, see e.g. Moriyasu Takao 森 安孝夫, “Nishi Uiguru ōkokushi no konpon shiryō toshiteno bōkui monjo 西ウイグル王 国史の根本史料としての棒杭文書 [Stake Inscriptions as the Fundamental Sources of the History of the West Uyghur Kingdom]," in Tōzai Uiguru to Chūō Yūrashia 東西ウイグ ルと中央ユーラシア [Eastern and Western Uyghurs and Central Eurasia], ed. Moriyasu Takao 森安孝夫 (Nagoya: Nagoya University publishers, 2015), 678-73o. The official financial support for the Buddhist temple discussed in section 4.2. above, is the only one which we know was given by an Uyghur ruler.

58 See BT XXvi, 37-44.

59 For the correct entries, which appear in this part, cf. BT XXVI, 43, table I.

6o See Dunhuang yuanwenji 敦煌願文集 [Collection of Prayer Texts from Dunhuang], comp. Huang Zheng 黄徵 and Wu Wei 吴偉 (Changsha: Yuelu shubanshe, 1995), e.g. 31, $319,334,338,445,459,483,487-488,492,521,524,587,598,6$ o5, and so on. Because several prayer texts mention the Tibetan king, the mention of the rulers seems to have become the concrete entry in the template of the prayer text already in the period of the Tibetan rule, see e.g. Dunhuang yuanwenji, 452, 555, 560.

61 See BT XXVI, 195-199, no. 10o, lines 20-23. Also, Akagi points out that one Chinese text mentions the Uyghur ruler, together with his wife and other subjects, and that he is there compared to a bodhisattva incarnate. Because of this text, Akagi assumes that the Uyghur rulers also used Buddhism to legitimate their rule, similar to those in Dunhuang and Khotan. See Akagi, "Kingship and the Idea of the Cakravartin," 253-254. In this case, however, it has to be understood on the basis of the Chinese tradition, and does not necessarily reflect the actual strategy of legitimation by the Uyghur rulers. 
during that period, although the structure of the dedication itself was certainly adopted in those colophons.

\subsection{Buddhism and Legitimation in the West Uyghur Kingdom}

As described above, the Uyghur rulers tried to keep a balance between the different religious communities, as well as controlling and supporting them at the same time. However, neither in the surviving visual materials nor in the written sources do we find any traces to demonstrate how ruling power played out in Buddhist contexts.

The Uyghur rulers' neighbours, the governors of Guiyijun, developed a new legitimation strategy in the 1oth century. It was probably partly caused by the demise of the Tang Dynasty, which was an important souce of legitimation for the Dunhuang rulers. In Dunhuang, where the Buddhists were the absolute majority and were diplomatically connected with their Buddhist neighbourhoods, Buddhist legitimation was a strategy that worked well. Compared with Dunhuang, the West Uyghur Kingdom had a strong need for legitimation of its foundation. At that time, it was not Buddhism, but Manichaeism and the kingdom's identity as the successor of the East Uyghur Kaganate that played crucial roles in formulating its legitimation. ${ }^{62}$ When Buddhism took over the role of state religion, the rule of the kingdom was stabilised, and the need for its legitimation was not as strong as in the former period. As the Buddhist adaptation of the ancestor legend shows, the Buddhists were eager to get the Uyghur rulers' favour. However, even during the period when Manichaeism kept its position as state religion, the local Buddhists seem to have enjoyed religious freedom without any constraints. ${ }^{63}$ In addition, as discussed in section 4.2 and 4.3 , they successfully got royal finantial support and acknowledgement through the appointment to various monks' positions by Uyghur rulers. Thus, it was not a life-or-death matter for the Buddhist community whether the Uyghur rulers officially demonstrate their power in Buddhist contexts or not, although it

62 As Wilkens points out in Chapter 7 of this volume, the Uyghurs kept using their self-designation 'Ten Uyghurs' (OU on uygur), something which originated in the period of the East Uyghur Kaganate. This designation appears not only in Manichaean but also in Buddhist texts. Therefore, it probably indicates that the Uyghurs continued to identify themselves as the successor of the East Uyghur Kaganate.

63 The Chinese ambassador Wang Yande (939-1006, 王延徳) for example, reports that in the West Uyghur Kingdom, he saw Buddhist temples with the name plaque bestowed by the Tang court over the gate. He visited the kingdom around 980, hence at that time the temples were still keeping their identification from the Tang period. Thus, they do not seem to have experienced serious destructions under the Uyghur Manichean rule. About the German translation of Wang Yande's report, see Moriyasu, Die Geschichte des uigurischen Manichäismus, 167-168. 
seems to have been considered desirable. Besides, the Buddhist community successfully received support from high-ranking Uyghurs, including members of the royal family, which would have been enough for the religion to enjoy its dominant position in the kingdom.

Moreover, the West Uyghur Kingdom seems to have established a cordial relationship with the Khitan Empire (907-1125, in Chinese sources known as Liao 遼), which ruled Manchuria, Mongolia, and northern parts of China, as well as its successor-state, the Kara Khitai (ca. 1124-1216, in Chinese sources known as Xiliao 西遼) in Central Asia. Thus, the connection with those protectorate powers could perhaps be seen as representing an alternative for the legitimation for the Uyghur rulers, such that Buddhism did not have to be the only medium available for the rulers. Furthermore, unlike in Dunhuang, in the West Uyghur Kingdom there were several religious groups, and even among the Buddhist communities, at least two different traditions were active. Also, to the west, the kingdom faced the Karakhanid Kaganate (999-1211), whose state religion was not Buddhism but Islam. Under these circumstances, it was probably not advisable to bring Buddhist legitimation of the rulers to the fore, to avoid a possible religious conflict between 'Buddhist' and 'Islamic' states. Mahmūd al-Kāšğarī (ca. 1020-ca. 1070) recorded in his book Dēwān Luġāt atTurk [Compendium of the Turkic Dialects] (composed in Baghdad in 1077) at least four poems of the Karahanid soldiers, who went to fight against the West Uyghur Kingdom. ${ }^{64}$ Among them, only one mentions the Buddhist worship of the Uyghurs, while none of the others describe those battles as something like a religious war (Arab. $\breve{g} i h \bar{a} d$, lit. striving or struggling) against the Buddhist Uyghurs-whom they considered to be idol worshippers (Arab. al-mušrikün). This is striking compared to the description of the Uyghur ruler as a protector of Manichaeanism in the Islamic sources from the former period.

The same impassive attitude of the Islamic states in regard to their non-Islamic neighbours, or rather their protectrate rulers, can be observed in what they report about the Kara Khitai Empire. ${ }^{65}$ This empire had its origin in the Khitan Empire, which was famous for its rulers' adherence to Buddhism. After the establishment of the Kara Khitai Empire, traces of Buddhist worship are no longer found. This empire conquered several Islamic states and would appear to have changed their religious adherence. At the same time, the Kara Khitai

64 See Robert Dankoff and James Kelly, trans., Mahmūd al-Kāšzarī. Compendium of the Turkic Dialects (Dīwān Lujāt at-Turk), 3 vols. (Cambridge: Harvard University Print. Office, 1982-1985), vol. 1, 270, 327, 359; and vol. 2, 272. There are two additional poems, which probably deal with the battle against the Uyghurs. See vol. 1, 353 and vol. 2, 245.

65 About this empire, see e.g. Michal Biran, The Empire of the Qara Khitai in Eurasian History. Between China and the Islamic World (Cambridge: Cambridge University Press, 2005). 
showed religious tolerance, because religion took a secondary position compared to the importance of trade in Central Asia. Its politics seem to have gained acceptance among its Islamic subject states, which submitted to its rule without any uprisings for most of the period in question. ${ }^{66}$

Probably the West Uyghur Kingdom also took the similar religious and political position politics as the state in Central Asia, where trade with neighbouring states in all directions was the most crucial issue and religion was a secondary issue. In that respect, the West Uyghur Kingdom was the forerunner of the Kara Khitai and belongs to those Central Asian states which were formerly nomadic and ruled mainly settled people after their migration.

\section{Legitimation in the Mongolian Period}

\subsection{Buddhist Legitimation of the Mongolian Emperors}

With the establishment of the Mongol Empire, the circumstances surrounding the Uyghurs and their kingdom changed dramatically. The Uyghur king voluntarily submitted to Činggiz Khan, because of which his kingdom enjoyed certain independence under Mongolian rule. Even so, the Mongolian emperors reigned supreme over the Uyghur kings, who came under their strategy of legitimation.

In the beginning, the Mongols probably had an idea of the power of their rulers, which was traditionally shared by nomadic tribes in Mongolia, including the Uyghurs, in the period of the East Uyghur Kaganate. From the moment that Khubilai Khan (r. 126o-1294) appointed Phakpa (1235-1280, Tib. 'Gro mgon chos rgyal 'Phags pa) as the Imperial Preceptor (Chin. dishi 帝師) in 1270, the Buddhist concept was established in which the Mongolian Great Khan was identified with a cakravartin. ${ }^{67}$

66 See Biran, The Empire of the Qara Khitai, 172-201.

67 See e.g. Ishihama Yumiko 石濱裕美子, "Pakupa no bukkyō shisō ni motoduku hubirai no ōkenzō ni tsuite パクパの仏教思想に基づくフビライの王権像について [Khubilai's King's Picture Based on Phakpa's Buddhist Concept]," Nihon seizō gakkai kaihō 日本 西蔵学会会報 [Report of the Japanese Association of Tibetan Studies] 40 (1994):35-44; Nakamura Jun 中村淳, "Chibetto to mongoru no kaikō-Harukanaru kōsei heno mebae一 チベットとモンゴルの邂逅一遥かなる後世へのめばえ— [Encounter between Tibet and Mongol—The Beginning of the Long History-]," in Chūō Yūrashia no tōgō 9-16 seiki. Iwanamikōza sekairekishin 中央ユーラシアの統合 9-16世紀 岩波講座 世界歴史11 [Fusion of Central Eurasia from the 9 th to the 16th Centuries. Series Iwanami World History 11], ed. Sugiyama Masa'aki 杉山正明 (Tokyo: Iwanami shoten, 1997): 135137 . 
This legitimation strategy was also demonstrated by cultural events that were carried out by orders from the Mongolian court in regard to important state celebrations. At these cultural events, the publication of various texts in different languages were organised. Buddhist texts in Old Uyghur were also chosen for such purposes. ${ }^{68}$ The use of the Old Uyghur texts in those events indicates that the Uyghur Buddhists and their texts played an essential role in the Mongolian court.

The Mongolian emperors' use of Buddhism as an element in their legitimation is also reflected in the Old Uyghur texts themselves. As mentioned above, in the donor colophons from the pre-Mongolian period, there are no specific entries by the rulers in the lists of dedication. However, in those from the Mongolian period, religious merit is often dedicated to the Mongolian emperor and his family members first, and one often finds the attribution that they 'belong to the bodhisattva clan' (OU bodis(a)t(a)v ugušlug). ${ }^{69}$ Their presence in the donor colophons indicates that the central position of the Mongolian emperors in Buddhist contexts was also employed by the Uyghur Buddhists.

\subsection{Uyghur Rulers in the Mongol Empire}

Under those circumstances, the Uyghur rulers themselves openly began to demonstrate their association with Buddhism. Although the Mongolian emperors and not the Uyghur rulers appear as entries in the dedication list of the colophons, the Uyghur rulers themselves acted as donors involved in the production of the Buddhist texts. ${ }^{70}$ Indeed, these activities seem to have been carried out because of the Uyghur rulers' private requests. Furthermore, as mentioned above, several Buddhist eulogies were written during the Mongolian period. The annals in Old Uyghur, which explains the history of the West Uyghur Kingdom with a Buddhist formulation, was also copied in that

68 See e.g. Nakamura Kentarō 中村健太郎, “Uigurubun 'Seisō Temuru sokui kinen butten' shuppan no rekishiteki haikei-U 4688 [T II S 63] • *U 9192 [T III M 182] no bunseki wo tsūjite- ウイグル文「成宗テムル即位記念仏典」出版の歴史的背景-U 4688 [T II S 63] •*U 9192 [T III M 182] の分析を通じて- [Historical Backgrounds of the Publication of Uyghur Buddhist Colophons Found in U 4688 [T II S 63] and *U 9192 [T III M 182]]," Nairiku ajia gengo no kenkyū 内陸アジア言語の研究 [Studies on the Inner Asian Languages] 21 (2006): 66-82.

69 See e.g. BT XXVI, 6o-61, no. 8a, lines 7-9, 112-115; no. 40, lines 31-32, 115-117; no. 41, lines 31-33, 122-123; no. 43, line 12, 132-134; no. 5o, lines 6-9, 207; no. 109, lines 5, 249-251; no. 133, line 13, 261-262; no. 144, lines 1-3, 262-263; no. 145, lines 6-17, 265-266; no. 149, lines 10-12, 266-267; and no. 15o, lines 1-2, 8-13.

70 The Uyghur ruler, Idok kut, is mentioned as a donor in several colophons. See BT XXVI, 112-115, no. 40, 261-262; no. 144, 265-266; and no. 149 . 
period. ${ }^{71}$ Because of the cursive writing of those eulogies and the Old Uyghur annals, they can be recognised as local or private productions. This indicates that the publication of Buddhist texts on the occasion of official celebrations was reserved for the priviledge of the Mongolian emperors, while the Uyghur rulers refrained from officially demonstrating their Buddhist position to avoid infringing on the majesty of the Mongolian emperors.

At least, however, one text indicates the official acknowledgment of the Uyghur rulers' position within a Buddhist context. The bilingual Old Uyghur-Chinese inscription Yidouhu gaochangwang shixunbei 亦都護高昌王世勲碑 [The Genealogical Memorial Inscription of the Idok kuts, Kings of Kočo], written in 1334, sets forth the Uyghur rulers' genealogy. There, the rulers appear several times with such different Buddhist attributes as bodhisattva (OU bodisatav), having come down from Tușita (Heaven) (OU tušittin inmišr) cintāmaṇi-like (OU čintamani täg), and so on..$^{72}$ Because of the official characteristic of that inscription, such descriptions indicate that the Uyghur rulers also sought to place their genealogy within a Buddhist context.

When the inscription was established, the Mongol Empire faced political instability. The ruling house of the Uyghur rulers themselves was divided into at least two factions. The ruling family shifted their residence from Turfan to Yongchang (永昌), due to the fight between the Great Khan and Khaidu (+1301), the grandson of Ögödei (r. 1229-1241), in the second half of the 13th century. ${ }^{73}$ While the rulers in Yongchang continuously served as subjects of the Mongol Empire, the new ruler was appointed in Kočo by the Čagatay rulers, who controlled the Turfan area. ${ }^{74}$ The fragmentation of the Uyghur ruling house and the loss of a direct connection to its original homeland caused the rulers' authority to degrade. Also, at this time, the authority of the Mongolian emperors

71 See section 5.2, fn. 55. Wilkens discusses the Uyghur rulers in Buddhist eulogies in Chapter 7 in this volume.

72 See e.g. Geng Shimin 耿世民, "Huihuwen 'yidouhu gaochangwang shixunbei' yanjiu 回鹘文《亦都护高昌王世勋碑》研究 [A Study of the Stone Tablet in Uyghur Script About the Meritorious Deeds of Princes of Kočo]," in Xinjiang wenshi lunji 新疆文史论 集 [Collection of the Papers on Language, Literature and History of Xinjiang], ed. Geng Shimin 耿世民 (Beijing: Zhongyang minzu daxue chubanshe, 2001), 400-434, esp. 404, line 22; 406, line 8 and 13. The article was first published in Kaogu xuebao 考古学報 [The Archaeological Journal] 4(1980):515-529; Shimin Geng and James Hamilton, "L'inscription ouïgoure de la stele commemorative des Idoq Qut de Qočo," Turcica 13 (1981): 18, line 22; 22 , line 8 and 13 .

73 See e.g. Thomas T. Allsen, "The Yüan Dynasty and the Uyghurs," in China among Equals. The Middle Kingdom and its Neighbors, 1oth-14th Centuries, ed. Morris Rossabi (Berkeley, Los Angeles, London: University of California Press, 1983), 252-255.

74 See e.g. Allsen, "The Yüan Dynasty and the Uyghurs," 258-26o; Rybatzki, "Titles of Türk and Uigur Rulers," 253-255. 
no longer served as a reliable source for the legitimation of the Uyghur rulers. Hence, the Uyghur rulers sought to establish their legitimation by positioning themselves within a Buddhist context.

\section{7}

\section{Closing Remarks}

The change in the rulers' titles in the East Uyghur Kaganate shows us that the beliefs chosen by the Uyghur rulers played an important role in legitimating their rule. The decision for the continuous royal support for Manichaean community and the change of the ruling clan of the East Uyghur Kaganate were probably important reasons for the introduction of the new Manichaean legitimation. When they migrated to the Eastern Tianshan area and founded the West Uyghur Kingdom, the first rulers who probably did not stem from the Yaglakar clan, the ruling clan of the East Uyghur Kaganate, had a strong need to legitimate their rule in order to stabilise their newly founded kingdom. Moreover, the Ganzhou Uyghur Kingdom, the rulers of which claimed they belonged to the Yaglakar clan, were the competing neighbouring state of the West Uyghur Kingdom. Because of that, the Uyghur ancestral legend was expanded so as to make it clear that the rulers of the new kingdom were the rightful successors to the East Uyghur Kaganate, both internally and externally. As a way of underscoring this, the rulers depicted themselves as protectors of Manichaeaism, and in return, the Manichaen community supported them with the production of a lot of hymns and eulogies dedicated to the rulers and their realm.

In the second half of the 1oth century, or at the beginning of the 11th century, Buddhism achieved the position of state religion in the West Uyghur Kingdom. Even so, the Uyghur rulers seem to have tried to deal with the different religious communities equally and refrained from engaging in any form of persecution. The fact that the Uyghur rulers appointed Buddhist monks to government positions and decided the size of the financial support of Buddhist monasteries indicates that the rulers were actively involved in the management and control of the religious communities under their rule, regardless of the shift of their religious favor.

During the 1oth century, in Dunhuang, Buddhist forms of legitimation in which the rulers positioned themselves as Buddhist kings, by calling themselves 'cakravartin', or 'bodhisattva king,' were demonstrated both in the visual and written materials. At that time, Dunhuang became more independent from the Chinese dynasties, and its rulers probably found it necessary to underline their Buddhist legitimation. On the other hand, the remaining 
materials do not show that the Uyghur rulers actively represented their power in a Buddhist context. The West Uyghur Kingdom already successfully stabilised its rule when Buddhism became the dominant religion of the Uyghurs, so that the rulers did not have a strong need to make their power visible with the support of Buddhist teachings.

Also, in the circumstances of the West Uyghur Kingdom, which had various religious groups under its rule, and the neighbouring Islamic states in the west, it was unadvisable to underline the Buddhist characteristics of their rule, both in domestic and diplomatic politics, to avoide provoking outspoken conflicts between different religious communities like other Central Asian states, since trade with neighbouring states was the most important issue to creating a stable financial base and religious differences were dealt with only secondarily. The close relationship of the West Uyghur Kingdom with the Khitan Empire, the other possible source of legitimation for the Uyghur rulers, could also be a reason why the Uyghurs did not necessarily depend on Buddhist legitimation alone.

During the Mongolian period, the Mongolian emperors systematically introduced Buddhist legitimation for their rule, and the Buddhist texts in Old Uyghur were used as part of this demonstration of allegiance. In this context, the Uyghur rulers also began to show their personal favor to Buddhism. Formal Buddhist legitimation was, however, preserved for the Mongolian emperors only. It only came to be used for the Uyghur rulers when both the Mongol Empire and the Uyghur ruling house experienced political instability, and the latter needed to legitimatise their power again. 